\title{
Eating out or in from home: Analyzing the quality of meal according eating locations
}

\section{$(1$}

Alimentação dentro ou fora do domicílio: análise

da qualidade da refeição segundo

o local de realização

Daniel Henrique BANDONI ${ }^{1}$

Daniela Silva CANELLA²

Renata Bertazzy LEVY ${ }^{3}$

Patricia Constante JAIME ${ }^{4}$

A B S T R A C T

\section{Objective}

The aim of this study was to evaluate the quality of meals consumed by workers from São Paulo according to eating location.

\section{Methods}

This cross-sectional study used the 24-hour recall to collect dietary data from 815 workers, including where the meal was consumed, and then grouped the meals by eating location: home, workplace cafeteria, and restaurant. Meal quality was assessed according to energy content and density, fiber density, and proportion of macronutrients, 10 food groups, and from sugar-sweetened beverages. These indicators and their respective eating locations were then included in linear regression models adjusted for gender, age, and education level.

\section{Results}

Meals consumed at workplace cafeterias had lower energy density, higher fiber density, and higher proportions of vegetables, fruits, and beans than those consumed at home. However, away-from-home meals contain more sugars, sweets, fats, and oils.

${ }^{1}$ Universidade Federal de São Paulo, Instituto de Saúde e Sociedade, Departamento de Saúde, Clínica e Instituições. R. Silva Jardim, 136, 11015-020, Santos, SP, Brasil. Correspondência para/Correspondence to: DH BANDONI. E-mail: <dbandoni@unifesp.br>.

2 Universidade de São Paulo, Faculdade de Saúde Pública, Pós-Graduação em Nutrição em Saúde Pública. São Paulo, SP, Brasil.

${ }^{3}$ Universidade de São Paulo, Faculdade de Medicina, Departamento de Medicina Preventiva. São Paulo, SP, Brasil.

${ }^{4}$ Universidade de São Paulo, Faculdade de Saúde Pública, Departamento de Nutrição. São Paulo, SP, Brasil. 
626 | DH BANDONI et al.

\section{Conclusion}

Eating location influences diet quality, so dietary surveys should assess meals consumed away from home more thoroughly since meal quality varies greatly by food service.

Indexing terms: Diet. Feeding behavior. Food services. Nutrition programs and policies. Workers.

\section{R E S U M O}

\section{Objetivo}

Analisar a qualidade da refeição de trabalhadores do município de São Paulo, segundo o local de realização da refeição.

\section{Métodos}

Estudo transversal, que avaliou a alimentação de 815 trabalhadores por meio de recordatório de 24 horas. Para o presente estudo, foram avaliados os dados do almoço dos trabalhadores, conforme o local de realização da refeição. Os locais foram agrupados em: domicilio, local de trabalho e restaurante comercial. Como indicadores de qualidade da refeição utilizou-se consumo de energia e densidade energética; participação calórica dos macronutrientes, de 10 grupos de alimentos e de bebidas açucaradas; e densidade de fibras. Comparou-se os indicadores brutos, segundo local de realização da refeição, por meio do teste analysis of variance, e os valores preditos para os indicadores, ajustados por sexo, idade e escolaridade, utilizando modelos de regressão linear múltipla.

\section{Resultados}

As refeições realizadas no local de trabalho apresentam menor densidade energética, maior densidade de fibras e maior participação de hortaliças, frutas e leguminosas, se comparadas às realizadas no domicílio. Por outro lado, as refeições realizadas em restaurantes comerciais resultaram em consumo superior de açúcares e doces e óleos e gorduras, quando comparadas àquelas realizadas no domicílio.

\section{Conclusão}

Há influência do local de realização da refeição na qualidade da alimentação, portanto, os inquéritos dietéticos devem avançar na questão da avaliação do consumo alimentar dentro ou fora do domicilio, fazendo-se necessário avaliar o local específico em que cada refeição é realizada.

Termos de indexação: Dieta. Comportamento alimentar. Serviços de alimentação. Programas e políticas de nutrição e alimentação. Trabalhadores.

\section{N TROD UCTIO N}

The consumption of foods away from home has increased in the last decades in the West. From 1987 to 2000 in the United States of America (USA), the number of Americans who ate away from home increased roughly $11 \%{ }^{1}$, and the number of food services almost doubled in 30 years, going from 491,000 in 1972 to 878,000 in $2004^{2}$.

In Brazil, meals away from home account for about $20 \%$ of food expenditures, reaching almost 30\% in higher income households and capitals $^{3}$. Data from the Associação Brasileira da Industria de Alimentos (ABIA, Brazilian Food
Industry Association) show that the mean annual growth of the food service market exceeds $10 \%$.

A recent household budget survey shows that the mean intake of energy away from home corresponds to approximately $16 \%$ of the total energy intake, being higher in urban areas, the Brazilian Southeast, males, and higher-income strata 4 .

Some studies have associated meals away from home with higher energy, fat, and sodium intakes, higher energy density, and lower fiber, iron, and vitamin intakes when compared with homemade meals $\mathrm{s}^{5-8}$.

In Brazil, soda, sandwiches, appetizers, and snack foods are an important part of meals away 
from home, showing that the quality of these meals may be poor ${ }^{4}$. Moreover, a study showed that meals away from home were associated with overweight and obesity in males and the opposite in females ${ }^{9}$.

Only a few studies have analyzed different eating locations and their impact on meal quality. Brazil has some public policies for food services, such as the Programa de Alimentação do Trabalhador (PAT, Worker's Food Program), whose objective is to improve workers' nutrition by subsidizing meals. Many workers covered by PAT eat at work cafeterias administered by dieticians. Other benefits include food stamps which can be used in member food services and groceries.

It is essential to assess the impact of eating location on energy, nutrient, and food group intakes. Hence, the present study aimed to analyze how eating location affected the quality of meals consumed by workers from the municipality of São Paulo.

\section{METHODS}

This cross-sectional study assessed the meals consumed by 831 workers from four companies in the municipality of São Paulo. The study workers were mostly administrative employees. Pregnant women and individuals who dieted and lost weight in the past six months and/ or used medications that could affect body weight were excluded. The baseline study data were obtained from the mother study entitled "Impact of an intervention to prevent weight gain at work" 10

Dietary data were collected from August to October 2008 by a 24-hour recall (24HR) using the Multiple Pass Method (MPM) administered by telephone ${ }^{11}$. The respondent is guided through five-step multiple-pass method (the quick list, the forgotten foods list, time and occasion at which foods were consumed, the detail cycle, and the final probe review) in a standardized process that aims to keep the interviewees interested and engaged in the interview, helping them to remember all items they consumed ${ }^{12}$. The meals were then grouped into homemade meals, workplace meals (prepared by the company's food service), and restaurant meals.

The 24HR data were converted into energy and nutrients by the software NutWin, updated with data from the Tabela Brasileira de Composição de Alimentos (TACO, Brazilian Food Composition Table) ${ }^{13}$ and United States Department of Agriculture Food Composition Table version 17 (USDA, 2006) $^{14}$. In addition to these data, standardized recipes were also loaded into the software to better represent the consumed foods.

Sixteen individuals were excluded from the study because their energy intakes were either too low or too high (P1 and P99 equivalent to $90.70 \mathrm{kcal}$ and $2062.88 \mathrm{kcal}$, respectively), resulting in a sample size of 815 workers.

The present study investigated only lunch since this was the only meal common to all workers.

The indicators used for assessing meal quality were energy intake (kcal); percentage of energy from each macronutrient; intake of the 10 food groups established by the Brazilian Food Guidelines ${ }^{15}$, namely grains, tubers and roots, non-starchy vegetables, fruits, beens, meats and eggs, milk and dairy products, oils and fats, sweets and sugars, and energy from sugar-sweetened beverages; energy density $(\mathrm{kcal} / \mathrm{g})$; and fiber density $(\mathrm{g} / 1000 \mathrm{kcal})$. The relative proportion of foods and macronutrients was expressed as percentages of total calorie intake. Energy density was determined as recommended by Ledikwe et al. 2005, who include all solid foods and exclude all beverages ${ }^{16}$.

Questionnaires standardized for characterizing the workers were administered in person at the workers' workplaces by trained interviewees. The collected variables were age (years), education level (years of formal education), and gender (male and female). 
The present study compared the lunch composition of different eating locations. The data were analyzed descriptively using frequency and measures of central tendency and dispersion. The differences between the raw quality indicator means of the eating locations were determined by analysis of variance (Anova). The same differences between the quality indicator means adjusted for gender, age, and education level were included in multiple linear regression models, with the dependent variables being the indicators, the explanatory variable, as an indicator, being the eating location, and the category of reference being the home.

The data were treated by the software Stata version 10.1 using a confidence interval of $95 \%$ and a significance level of $5 \%$.

This study was approved by the Research Ethics Committee of University of São Paulo's School of Public Health under protocol number 1996 and followed the National Health Council's Resolution 196/96. All participants signed a free and informed consent form before entering the study.

\section{RE S U LT S}

A total of 815 adults were studied, of which $60.4 \%$ were females, $64.8 \%$ were aged 26 to 45 years, and $52.9 \%$ had higher education. Most participants had lunch in restaurants (37.1\%) or workplace (35.7\%), and less than one-third had lunch at home (Table 1).

Table 2 shows the mean intake of calories, macronutrients, and food groups according to eating location. Individuals who ate at work cafeterias consumed fewer calories (640.34kcal), less dense meals $(1.42 \mathrm{kcal} / \mathrm{g})$, more non-starchy vegetables $(3.28 \%)$, more fruits $(5.32 \%)$, and more beens $(6.07 \%)$. Those who ate at restaurants consumed more meats $(32.16 \%)$ and sugars and sweets (6.49\%). Finally, those who ate at home consumed more grains and roots and tubers (38.52\%), and less oils and fats (9.19\%) and sugars and sweets (3.87\%).
Linear regression models were used for adjusting the mean calorie, macronutrient, and food group intakes according to sociodemographic variables (Table 3). Meals consumed at workplace cafeterias were less dense $(1.67 \mathrm{kcal} / \mathrm{g})$ and contained more fibers $(14.15 \mathrm{~g} / 1000 \mathrm{kcal})$, nonstarchy vegetables $(3.23 \%)$, fruits $(5.31 \%)$, and beens $(5.94 \%)$ than those consumed at home. On the other hand, meals consumed at workplace cafeterias and restaurants contained more sugars and sweets, oils, and fats than those consumed at home. Meals consumed in restaurants contained more fats, proteins, and calories from meats.

\section{DISCUSSION}

The present study assessed the quality of meals consumed by workers at different eating locations and found that meals consumed at workplace cafeterias were less energy dense and contained more calories from non-starchy vegetables, fruits, and beens than those consumed at home. On the other hand, meals consumed in restaurants containing more fats, proteins, and calories from meats.

Table 1. Sociodemographic variables and lunch eating locations of workers in the city of São Paulo (SP), Brazil, 2008.

\begin{tabular}{lcc}
\hline Caracteristic & $\mathrm{n}$ & $\%$ \\
\hline Sex & & \\
Female & 492 & 60.4 \\
Male & 323 & 39.6 \\
Age & & \\
$18-25$ & 185 & 22.7 \\
$26-35$ & 314 & 38.5 \\
$36-45$ & 214 & 26.3 \\
46 or more & 102 & 12.5 \\
Education & & \\
Higt School & 174 & 21.3 \\
Some college & 210 & 25.8 \\
Graduate & 431 & 52.9 \\
Lunch eating location & & \\
Home & 222 & 27.2 \\
Workplace & 291 & 35.7 \\
Restaurants & 302 & 100.0 \\
\hline Total & 815 & \\
\hline
\end{tabular}


Table 2. Mean (C195\%) of the energy consumption, macronutrients and food groups at lunch, according lunch eating locations, the workers in the city of São Paulo (SP), Brazil, 2008.

\begin{tabular}{|c|c|c|c|c|c|c|c|c|c|}
\hline \multirow{4}{*}{$\begin{array}{l}\text { Nutrient/Food group } \\
\text { Energy }(\mathrm{kcal})^{*}\end{array}$} & \multicolumn{9}{|c|}{ Lunch Eating Locations } \\
\hline & \multicolumn{3}{|c|}{ Home } & \multicolumn{3}{|c|}{ Workplace } & \multicolumn{3}{|c|}{ Restaurants } \\
\hline & \multirow{2}{*}{$\frac{\text { Mean }}{701.42}$} & \multicolumn{2}{|c|}{$\mathrm{Cl}$} & \multirow{2}{*}{$\frac{\text { Mean }}{640.34}$} & \multicolumn{2}{|c|}{$\mathrm{Cl}$} & \multirow{2}{*}{$\frac{\text { Mean }}{740.74}$} & \multicolumn{2}{|c|}{$\mathrm{Cl}$} \\
\hline & & 656.65 & 746.18 & & 602.52 & 678.16 & & 704.29 & 777.19 \\
\hline Energy Density $(\mathrm{kcal} / \mathrm{g})^{*}$ & 1.57 & 1.50 & 1.64 & 1.42 & 1.35 & 1.49 & 1.56 & 1.49 & 1.62 \\
\hline Carbohydrates $(\%)^{*}$ & 49.49 & 47.32 & 51.66 & 46.22 & 44.59 & 47.84 & 43.47 & 41.63 & 45.31 \\
\hline Total Fat $(\%)^{*}$ & 26.23 & 24.56 & 27.90 & 28.89 & 27.66 & 30.13 & 29.66 & 28.38 & 30.95 \\
\hline Protein $(\%)^{*}$ & 24.28 & 23.00 & 25.57 & 24.89 & 23.62 & 26.16 & 26.87 & 25.57 & 28.17 \\
\hline Dietary fiber density $(\mathrm{g} / 1000 \mathrm{kcal})^{*}$ & 11.59 & 10.55 & 12.63 & 14.12 & 13.13 & 15.11 & 11.63 & 10.79 & 12.47 \\
\hline Group of cereal, tubers and roots $(\%)^{*}$ & 38.52 & 35.86 & 41.18 & 25.36 & 23.65 & 27.06 & 24.48 & 22.78 & 26.18 \\
\hline Group of vegetables $(\%)^{*}$ & 2.18 & 1.86 & 2.49 & 3.28 & 2.87 & 3.68 & 2.98 & 2.65 & 3.32 \\
\hline Group of fruits $(\%)^{*}$ & 1.20 & 0.71 & 1.69 & 5.32 & 4.31 & 6.34 & 4.49 & 3.39 & 5.59 \\
\hline Group of beens $(\%)^{*}$ & 2.98 & 2.10 & 3.87 & 6.07 & 4.78 & 7.37 & 4.47 & 3.31 & 5.63 \\
\hline Group meats and eggs $(\%)^{*}$ & 27.74 & 25.22 & 30.27 & 28.59 & 26.58 & 30.59 & 32.16 & 29.95 & 34.37 \\
\hline Group of milk and dairy products (\%) & 3.80 & 2.96 & 4.64 & 6.04 & 5.13 & 6.94 & 4.04 & 3.42 & 4.66 \\
\hline Group of oils and fats (\%) ${ }^{*}$ & 9.19 & 8.26 & 10.12 & 11.19 & 10.35 & 12.02 & 10.38 & 9.45 & 11.30 \\
\hline Group of sweets and sugars (\%) ${ }^{*}$ & 3.87 & 2.63 & 5.10 & 6.26 & 5.03 & 7.50 & 6.49 & 5.09 & 7.89 \\
\hline Sugar-Sweetened Beverages (\%) & 5.66 & 4.42 & 6.90 & 4.30 & 3.37 & 5.23 & 4.74 & 3.57 & 5.90 \\
\hline
\end{tabular}

Note: ${ }^{*} p<0.05$ by Analysis of variance test for difference between means.

Table 3. Mean (95\%), adjusted for sex, age and education, of the energy consumption, macronutrients and food groups at lunch, according lunch eating locations, the workers in the city of São Paulo (SP), Brazil, 2008.

\begin{tabular}{|c|c|c|c|c|c|c|c|c|c|}
\hline \multirow{3}{*}{ Nutrient/Food group } & \multicolumn{9}{|c|}{ Lunch Eating Locations } \\
\hline & \multicolumn{3}{|c|}{ Home } & \multicolumn{3}{|c|}{ Workplace } & \multicolumn{3}{|c|}{ Restaurants } \\
\hline & Mean & & $\mathrm{Cl}$ & Mean & & $\mathrm{Cl}$ & Mean & & $\mathrm{Cl}$ \\
\hline Energy $(k c a l)^{*}$ & 703.86 & 661.84 & 745.87 & 651.44 & 614.73 & 688.15 & 728.26 & 691.94 & 764.565 \\
\hline Energy Density $(\mathrm{kcal} / \mathrm{g})^{*}$ & 1.78 & 1.72 & 1.84 & 1.67 & 1.62 & 1.72 & 1.77 & 1.71 & 1.82 \\
\hline Carbohydrates $(\%)^{*}$ & 49.27 & 47.22 & 51.33 & 46.19 & 44.39 & 47.99 & 43.65 & 41.88 & 45.43 \\
\hline Total Fat $(\%)^{*}$ & 26.31 & 24.80 & 27.82 & 28.77 & 27.45 & 30.08 & 29.72 & 28.42 & 31.03 \\
\hline Protein $(\%)^{*}$ & 24.41 & 22.99 & 25.85 & 25.04 & 23.79 & 26.29 & 26.62 & 25.39 & 27.87 \\
\hline Dietary fiber density $(\mathrm{g} / 1000 \mathrm{kcal})^{*}$ & 11.53 & 10.48 & 12.58 & 14.15 & 13.23 & 15.07 & 11.64 & 10.73 & 12.55 \\
\hline Group of cereal, tubers and roots (\%) & 38.37 & 36.20 & 40.56 & 25.37 & 23.47 & 27.28 & 24.56 & 22.68 & 26.45 \\
\hline Group of vegetables $(\%)^{*}$ & 2.17 & 1.77 & 2.56 & 3.23 & 2.88 & 3.58 & 3.03 & 2.69 & 3.38 \\
\hline Group of fruits $(\%)^{*}$ & 1.14 & 0.06 & 2.22 & 5.31 & 4.37 & 6.26 & 4.54 & 3.61 & 5.47 \\
\hline Group of beens $(\%)^{*}$ & 3.04 & 1.75 & 4.33 & 5.94 & 4.81 & 7.06 & 4.56 & 3.45 & 5.67 \\
\hline Group meats and eggs $(\%)^{*}$ & 27.97 & 25.51 & 30.43 & 28.87 & 26.72 & 31.03 & 31.71 & 29.58 & 33.83 \\
\hline Group of milk and dairy products (\%) & 3.77 & 2.90 & 4.64 & 6.12 & 5.36 & 6.89 & 3.98 & 3.22 & 4.73 \\
\hline Group of oils and fats $(\%)^{*}$ & 9.16 & 8.16 & 10.15 & 11.05 & 10.18 & 11.92 & 10.56 & 9.70 & 11.42 \\
\hline Group of sweets and sugars (\%) ${ }^{*}$ & 3.82 & 2.37 & 5.27 & 6.09 & 4.81 & 7.36 & 6.63 & 5.37 & 7.89 \\
\hline Sugar-Sweetened Beverages (\%) & 5.68 & 4.46 & 6.89 & 4.39 & 3.32 & 5.46 & 4.68 & 3.62 & 5.73 \\
\hline
\end{tabular}

Note: ${ }^{*} p<0.05$ in the linear regression model adjusted for sociodemographic variables (sex, age and education).

The main limitation of this study is that it was not possible to correct intrapersonal data variability to show the workers' habitual diet because the workers did not always eat at the same location. Another limitation was analyzing a single meal, lunch, since this was the only meal consumed away from home common to all workers, making it impossible to analyze daily food consumption according to eating location. However, although these limitations can weaken 
the regression coefficients, it is unlikely that inexistent associations emerge as significant, which strengthens the study results ${ }^{17}$.

Many studies have analyzed eating location to compare meals made at home and away from home, types of restaurants, or consumed foods ${ }^{18-21}$. Even Brazilian studies have failed to analyze meals consumed at work cafeterias.

The Workers' Food Program (Programa de Alimentação do Trabalhador - PAT) was created in 1976 to improve workers' nutrition ${ }^{22}$. Today it covers more than fourteen million workers. Despite its importance and extensive coverage, few studies have investigated the impact of PAT on workers' health, and many studies question the effectiveness of the program in promoting their health22-24. Therefore, studies about the quality of meals consumed away from home in Brazil should include workplace, as they are an important eating location.

After adjustment, the energy content of the meals consumed at different eating locations did not vary significantly, but their quality indicators did. In general, meals realized in the workplace cafeteria have the best results. Their higher quality may be related to PAT's nutritional guidelines set forth by the Interministerial Decree of 2006, which established limits for the macronutrient distribution and energy, saturated fat, fiber, and sodium contents and determined the inclusion of non-starchy vegetables and fruits ${ }^{25}$.

Energy density is influenced by water and fat content ${ }^{26}$. Hence, the lower energy density of workplace meals is related to their total fat and fiber contents, different from those of homemade meals. However, in all study locations, energy density is higher than that recommended by the World Cancer Research Fund, which recommends a dietary energy density of $1.25 \mathrm{kcal} / \mathrm{g}$ as a public health goal27.

The higher fiber intake of individuals who eat at workplace cafeterias stems from a higher intake of fruits, non-starchy vegetables, and legumes. A study found that PAT workers' lunch contains $6.0 \mathrm{~g}$ to $8.3 \mathrm{~g}$ of fiber ${ }^{23}$. Other studies found that fiber intake away from home is lower than that at home ${ }^{6,8}$, but these studies have not assessed fiber intake according to eating location.

In Brazil, less than $45 \%$ of the adult population consumes fruits and non-starchy vegetables regularly, and only $7.3 \%$ has an adequate intake of these foods ${ }^{28}$. Thus, the higher intake of fruits and non-starchy vegetables at workplace cafeterias as opposed to homes and restaurants may be related to PAT nutritional guidelines, which establish that companies must include at least one serving of non-starchy vegetables and one of fruits in main meals, such as lunch ${ }^{25}$. This hypothesis is reinforced by findings of an interventional study at the workplace that found that a greater availability of fruits and non-starchy vegetables increases their intake ${ }^{29}$.

Been intake was also higher among those eating at workplaces. This result is not surprising since rice and beans are staples in cafeterias - they are served daily. However, at-home consumption of rice and beans has decreased considerably in the last years ${ }^{30,31}$.

Restaurant meals contained more meat, and, indeed, intake of this food group would hardly be high at workplace because there meats are doled out, and at home, because meats are expensive. Furthermore, people perceive foods consumed at home and away from home differently. For instance, meats should always be included in away-from-home meals because of variety and their possible unavailability at home ${ }^{32}$.

The greater amount of calories from oils and fats in workplace cafeteria meals is corroborated by a study that assessed the menu of companies in São Paulo and found the total fat content to be excessive ${ }^{33}$. However, the present study did not assess fat quality, and all study restaurants used vegetable oils for cooking. Increasing the fat content may be a strategy to increase palatability, making foods desirable. This practice did not occur at home, since the proportion of oils and fats in homemade meals was smaller. 
Individuals who ate at workplace cafeterias and restaurants also consumed more sugars and sweets, which is confirmed by other Brazilian studies. Soda and sweets are the first and third most consumed food items away from home in Brazill20, and companies in São Paulo frequently offer too much free sugar ${ }^{33}$.

In conclusion, it is important to assess not only if foods are consumed at home or away from home, but also eating location, it was found that meals realized in the workplace have lower energy density and higher amounts of fruits, non-starchy vegetables, fibers, and beens. Their quality was also considered better than that of homemade and restaurant meals. However, people should pay attention to the offer of high-fat foods and sweets in workplace cafeterias.

These findings reinforce the importance of PAT encouraging member companies to have food services, for healthy foods improve workers' diets. The present study is the first in Brazil to assess meal quality according to eating location, showing that the latter may influence one's diet.

\section{CONTRIBUTORS}

All authors participated in all phases of the research article.

\section{REFERENCES}

1. Kant AK, Graubard BI. Eating out in America, 19872000: Trends and nutritional correlates. Prev Med. 2004; 38(2):243-9.

2. United States Departament of Agriculture. The Keystone Forum on Away-from-home Foods: Opportunities for preventing weight gain and obesity. The Keystone Center: Washington (DC); 2006.

3. Claro RF, Levy RB, Bandoni DH. Influência da renda sobre as despesas com alimentação fora do domicílio no Brasil, 2002-2003. Cad. Saúde Pública 2009; 25(8):2489-96.

4. Instituto Brasileiro de Geografia e Estatística. Pesquisa de orçamentos familiares 2008-2009: análise do consumo alimentar pessoal no Brasil. Rio de Janeiro: IBGE; 2011.

5. Kearney JM, Hulshof KF, Gibney MJ. Eating patterns - temporal distribution, converging and diverging foods, meals eaten inside and outside of the home - implications for developing FBDG. Public Health Nutr. 2001; 4(2B):693-8.

6. Guthrie JF, Lin BH, Frazao E. Role of food prepared away from home in the American diet, 1977-78 versus 1994-96: Changes and consequences. J Nutr Educ Behav. 2002; 34(3):140-50.

7. Nielsen SJ, Siega-Riz AM, Popkin BM. Trends in food locations and sources among adolescents and young adults. Prev Med. 2002; 35(2):107-13.

8. Orfanos P, Naska A, Trichopoulou A, Grioni S, Boer JMA, van Bakel MME et al. Eating out of home: Energy, macro- and micronutrient intakes in 10 European countries. The European Prospective Investigation into Cancer and Nutrition. Eur J Clin Nutr. 2009; 63(S4):S239-S62.

9. Bezerra IN, Sichieri R. Eating out of home and obesity: A Brazilian nationwide survey. Public Health Nutr. 2009; 12(11):2037-43.

10. Jaime, PC, Bandoni, H, Sarno F. Impacto of an education intervention using email for the prevention of weight gain among adult workers. Public Health Nutr. 2013 [cited 2013 Aug]; 20:1-8. Available from: <http://www.ncbi.nlm.nih.gov/ pubmed/23962422>. [Epub ahead of print].

11. Rutishauser IHE. Dietary intake measurements. Public Health Nutr. 2002; 8(7A):1100-1107.

12. Conway JM, Ingwersen LA, Moshfegh AJ. Accuracy of dietary recall using the USDA five-step multiplepass method in men: An observational validation study. J Am Diet Assoc. 2004; 104(4):595-603.

13. Universidade Estadual de Campinas. Tabela brasileira de composição de alimentos: versão II. $2^{\mathrm{a}}$ ed. Campinas: Unicamp; 2006.

14. United States Departament of Agriculture. Nutrient data laboratory. Washington (DC): United States Departament of Agriculture. [cited 2006 Nov 7]. Available from: <http://www.nal.usda.gov/fnic/ foodcomp>.

15. Brasil. Ministério da Saúde, Guia alimentar para a população brasileira: promovendo a alimentação saudável. Brasília: Ministéro da Saúde; 2005.

16. Ledikwe JH, Blanck HM, Khan LK, Serdula MK, Seymour JD, Tohill BC, et al. Dietary energy density determined by eight calculation methods in a nationally representative United States population. J Nutr. 2005; 135(1):273-8.

17. Orfanos P, Knüppel S, Naska A, Haubrock J, Trichopoulou A, Boeing $\mathrm{H}$. Evaluating the effect of 
measurement error when using one or two $24 \mathrm{~h}$ dietary recalls to assess eating out: A study in the context of the HECTOR project. Br J Nutr. 2013; 110(6):1107-17.

18. Duffey KJ, Gordon-Larsen P, Steffen LM, Jacobs Jr DR, Popkin BM. Regular consumption from fast food establishments relative to other restaurants is differentially associated with metabolic outcomes in young adults. J Nutr. 2009; 139(11):2113-8.

19. Bes-Rastrollo M, Basterra-Gortari FJ, SánchezVillegas A, Marti A, Martínez JA, Martínez-González MA. A prospective study of eating away-from-home meals and weight gain in a Mediterranean population: The SUN (Seguimiento Universidad de Navarra) cohort. Public Health Nutr. 2010; 13(9): 1356-63.

20. Bezerra IN, Sichieri R. Características e gastos com alimentação fora do domicílio no Brasil. Rev Saúde Pública. 2010; 44(2):221-9.

21. Sanches M, Salay E. Alimentação fora do domicílio de consumidores do município de Campinas, São Paulo. Rev Nutr. 2011; 24(2):295-304. doi: 10.15 90/S1415-52732011000200010.

22, L'Abbate $S$. As políticas de alimentação e nutrição no Brasil: a partir dos anos setenta. Rev Nutr. 1989; 2(1):7-54

23. Sávio KEO, Costa THM da, Miazaki E, Schmitz BAS. Avaliação do almoço servido a participantes do programa de alimentação do trabalhador. Rev Saúde Pública 2005; 39(2):148-55.

24. Bandoni DH, Brasil BG, Jaime PC. Programa de alimentação do trabalhador: representações sociais de gestores locais. Rev Saúde Pública; 40(5): 837-842.

25. Brasil. Ministério do Trabalho e Emprego. Portaria Interministerial $n^{\circ}$ 66, de 25 de agosto de 2006. Altera os parâmetros nutricionais do Programa de Alimentação do Trabalhador - PAT. Diário Oficial da União. 200628 ago.
26. Crowe TC, La Fontaine HA, Gibbons CJ, CameronSmith D, Swinburn BA. Energy density of foods and beverages in the Australian food supply: Influence of macronutrients and comparison to dietary intake. Eur J Clin Nutr. 2004; 58(11):1485-91.

27. World Cancer Research Fund. American Institute for Cancer Research. Food, Nutrition, Physical Activity, and the Prevention of Cancer: A Global Perspective. Washington (DC): AICR, 2007.

28. Jaime PC, Figueiredo ICR, Moura EC, Malta DC. Fatores associados ao consumo de frutas e hortaliças no Brasil, 2006. Rev Saúde Pública. 2009; 43(Suppl 2):57-64.

29. Bandoni DH, Sarno F, Jaime PC. Impact of an intervention on the availability and consumption of fruits and vegetables in the workplace. Public Health Nutr. 2011; 14(6):975-81.

30. Levy-Costa RB, Sichieri R, Pontes NS, Monteiro CA. Disponibilidade domiciliar de alimentos no Brasil: distribuição e evolução (1974-2003). Rev Saúde Pública. 2005; 39(4):530-40.

31. Levy RB, Claro RM, Mondini L, Sichieri R, Monteiro CA. Distribuição regional e socioeconômica da disponibilidade domiciliar de alimentos no Brasil em 2008-2009. Rev Saúde Pública. 2012; 46(1):6-15.

32. Garcia RWD. Práticas e comportamento alimentar no meio urbano: um estudo no centro da cidade de São Paulo. Cad Saúde Pública. 1997; 13(3):455-67.

33. Geraldo APG, Bandoni DH, Jaime PC. Aspectos dietéticos das refeições oferecidas por empresas participantes do Programa de Alimentação do Trabalhador na Cidade de São Paulo, Brasil. Rev Panam Salud Publica. 2008; 23(1):19-25.

Received on: 5/7/2012

Final version on: 13/9/2013 Approved on: 7/10/2013 